\title{
УДК 338.242.4
}

\section{JEL Classification: L500}

\section{Сментина Наталія, Фіалковська Анастасія, Іюкко Ігор}

\section{СУЧАСНИЙ СТАН ТА ПЕРСПЕКТИВИ РОЗВИТКУ ІТ-ІНДУСТРІЇ В УКРАЇНІ В КОНТЕКСТІ ТРАНСФОРМАЦІї ДЕРЖАВНОЇ РЕГУЛЯТОРНОЇ ПОЛІТИКИ}

Анотація. У статті зосереджено увагу на сучасному стані та перспективах IT-індустрії, розвиток якої визначає економічний потенціал держави та якість життя її громадян, а також роль і місце української держави в глобальному суспільстві, масштаби та перспективи її економічної та політичної інтеграції з усім світом. Визначено, що державна політика у секторі інформаційних технологій формується як складова частина соціально-економічної політики держави. Метою державної політики інформатизації є сприяння побудові сучасної ринкової економіки, забезпечення підвищення конкурентоспроможності національної економіки шляхом впровадження сучасних та перспективних інформаційно-комунікаційних технологій в усі сфери життєдіяльності українського суспільства. Відмічено поділ сукупності інструментів державної політики інформатизації на правові та економічні регулятори. 3'ясовано місце сектору IT України серед інших видів економічної діяльності в структурі ВВП. Визначено, що українська ITгалузь успішно конкурує на світовому ринку, проте цифрова конкурентоспроможність національної економіки доволі слабка. Проаналізовано місце України у рейтингу цифрової конкурентоспроможності у динаміці. Акцентовано увагу на тому, що життєво важливим фактором та підгрунтям для функціонування та розвитку української ІТ-індустрії є екосистема, що поєднує в собі профільні бізнес-асоціації, інфраструктуру стартапів, регіональні об'єднання (кластери), заклади вищої освіти, що активно розвивають напрям технічної освіти, та приватні освітні проекти, інноваційні парки, технологічні хаби, масштабні індустріальні події, професіональні формальні та неформальні спільноти. Запропоновані економічні інструменти державної регуляторної політики, застосування яких сприятиме подальшому розвитку і реалізації потенціалу ІТ-сфери України. Описано два сценарії перспективного розвитку IT-індустрії. Побудовано модель залежності обсягу ринку IT від обсягу капітальних інвестицій та обсяг експорту. За допомогою двофакторного кореляційно-регресійного аналізу спрогнозовано загальний обсяг ринку IT в Україні.

Ключові слова: ІТ-індустрія, державна регуляторна політика, інформатизація, правові регулятори, економічні інструменти, цифрова конкурентоспроможність, екосистема. 
Smentyna Nataliia, Fialkovska Anastasiia, Izhko Igor

\title{
CURRENT SITUATION AND PROSPECTS DEVELOPING OF UKRAINIAN IT-INDUSTRY IN THE CONTEXT OF STATE REGULATORY POLICY
}

\begin{abstract}
The article deals with the current state and prospects of the IT-industry development that determines the economic potential of the country and the quality of life of its citizens, as well as the role and place of this country in the global society, the scope and prospects of its economic and political integration with the world. It has been determined in the article that the state policy in the information technology sector forms as an integral part of the socio-economic policy of the state. The aim of the state policy of informatization is to promote the creation of a modern market economy, to ensure the competitiveness of the national economy by introducing modern and promising information and communication technologies into all spheres of the Ukrainian society. The separation of information policy tools into legal and economic regulators has been noted. The place of the IT-sector of Ukraine among other types of economic activity in the structure of GDP has been found out. It has been determined that the Ukrainian IT-industry successfully competing in the world market, but the digital competitiveness of the national economy is considered to be weak. The place of Ukraine in the rating of digital competitiveness in dynamics has been analyzed. Attention has been drawn to the fact that a vital factor and foundation for the functioning and development of the Ukrainian IT industry is an ecosystem that combines profile business associations, startup infrastructure, regional associations (clusters), higher education institutions that are actively developing direction, technical education and private education projects, innovation parks, technology hubs, large-scale industrial events, professional formal and informal communities. Economic instruments of state regulatory policy have been proposed. Their application will further develop and realize the potential of Ukraine's IT-sphere. Two scenarios of prospective development of the IT-industry have been described. The model of dependence of the IT-market volume on the volume of capital investments and volume of export has been elaborated. The total IT-market in Ukraine has been predicted by means of two-factor correlation and regression analysis.
\end{abstract}

Keywords: IT-industry, state regulatory policy, informatization, legal regulators, economic instruments, digital competitiveness, ecosystem.

\section{Сментына Наталия, Фиалковская Анастасия, Ижко Игорь}

\section{СОВРЕМЕННОЕ СОСТОЯНИЕ И ПЕРСПЕКТИВЫ РАЗВИТИЯ ИТ-ИНДУСТРИИ В УКРАИНЕ В КОНТЕКСТЕ ТРАНСФОРМАЦИИ ГОСУДАРСТВЕННОЙ РЕГУЛЯТОРНОЙ ПОЛИТИКИ}

Аннотация. В статье сосредоточено внимание на современном состоянии и перспективах ИТ-индустрии, развитие которой определяет экономический по- 
тенциал государства, качество жизни населения, проживающего на его территории, а также роль и место украинского государства в глобальном обществе, масштабы и перспективы его экономической и политической интеграции со всем миром. Определено, что государственная политика в секторе информационных технологий формируется как составная часть социально-экономической политики государства. Целью государственной политики информатизации является содействие построению современной рыночной экономики, обеспечение повышения конкурентоспособности национальной экономики посредством внедрения современных и перспективных информационно-коммуникационных технологий во все сферы жизнедеятельности украинского общества. Отмечается деление совокупности инструментов государственной политики информатизации на правовые и экономические регуляторы. Показано место сектора ИТ Украины среди других видов экономической деятельности в структуре ВВП. Определено, что украинская ИТ-отрасль успешно конкурирует на мировом рынке, однако цифровая конкурентоспособность национальной экономики довольно низкая. Проанализировано место Украины в рейтинге цифровой конкурентоспособности в динамике. Акцентировано внимание на том, что жизненно важным фактором и основой для функционирования и развития украинской IT-индустрии является экосистема, которая объединяет в себе профильные бизнес-ассоциации, инфраструктуру стартапов, региональные объединения (кластеры), высшие учебные заведения, инновационные парки, технологические хабы, профессиональные формальные и неформальные сообщества. Предложены экономические инструменты государственной регуляторной политики, внедрение которых будет способствовать дальнейшему развитию и реализации потенциала ИТ-сферы Украины. Описаны два сценария перспективного развития ИТ-индустрии. Построена модель зависимости объема рынка ИТ от объема капитальных инвестиций и объема экспорта. С помощью двухфакторного корреляционно-регрессионного анализа спрогнозирован общий объем рынка ИТ в Украине.

Ключевые слова: ИТ-индустрия, государственная регуляторная политика, информатизация, правовые регуляторы, экономические инструменты, цифровая конкурентоспособность, экосистема.

\section{DOI: 10.32680/2409-9260-2019-7-8-270-271-129-142}

\section{Постановка проблеми в загальному вигляді та їі зв'язок $з$ важ-} ливими науковими або практичними завданнями. В сучасних умовах господарювання головним драйвером світової економіки, каталізатором для трансформацій у багатьох інших індустріях є сфера інформаційних технологій. Багато країн світу переконалися у тому, що розвиток IT-індустрії визначає не лише економічний потенціал держави та якість життя їі громадян, а й роль і місце цієї країни в глобально- 
му суспільстві, масштаби та перспективи їі економічної та політичної інтеграції з усім світом.

3 огляду на те, що сфера інформаційних технологій стає рушієм соціально-економічного розвитку держави, посилюється роль публічного сектору до іiї розвитку. Стійкий і динамічний розвиток IT-індустрії зумовлює появу низки правових та економічних регуляторів, добір та застосування яких відбувається на засадах, з одного боку системного, з іншого - програмно-цільового підходу до управління.

Аналіз останніх досліджень і публікацій, в яких покладений початок вирішенню даної проблеми і на які спирається автор. Проблема дослідження інструментів та механізмів підтримки та стимулювання розвитку IT-індустрії з боку держави є об’єктом дослідження багатьох українських учених-економістів, зокрема таких як: Н. Грицяк, Л. Литвинова, які узагальнили основні засади державної регуляторної політики щодо формування інформаційного суспільства у контексті євроінтеграційних процесів; П. Куцик, А. Процикевич, що приділили увагу концептуальним характеристикам системи державного регулювання розвитку ринку IT-послуг; О. Кохановська, об'єктом дослідження якої стали джерела регулювання інформаційних відносин в Україні; К. Пестова, В. Кравчук, що зосередили увагу на публічно-правових проблемах IT-сфери.

Виділення невирішених раніше частин загальної проблеми, котрим присвячується стаття. Не зважаючи на посилену увагу науковців до пошуку відповідного інструментарію державної регуляторної політики у сфері інформаційних технологій, стрімкі темпи розвитку галузі потребують подальшої постійної уваги, зокрема науковців для розроблення дієвих механізмів стимулювання розвитку сфери та використання новітніх інструментів державної регуляторної політики.

Формулювання мети статті (постановка завдання). Метою статті є дослідження сучасного стану розвитку IT-індустрії в Україні, узагальнення теоретико-прикладних аспектів державної регуляторної політики та визначення перспектив розвитку інформаційних технологій.

Викладення основного матеріалу дослідження з повним обгрунтуванням отриманих наукових результатів. Варто відмітити, що державна політика у секторі інформаційних технологій носить назву державної політики інформатизації. Вона формується як складова частина соціально-економічної політики держави в цілому і спрямовується 
на раціональне використання промислового та науково-технічного потенціалу, матеріально-технічних і фінансових ресурсів для створення сучасної інформаційної інфраструктури в інтересах вирішення комплексу поточних та перспективних завдань розвитку України як незалежної демократичної держави з ринковою економікою. Основною метою цієї політики є сприяння побудові сучасної ринкової економіки, забезпечення підвищення конкурентоспроможності національної економіки шляхом впровадження сучасних та перспективних інформаційно-комунікаційних технологій в усі сфери життєдіяльності українського суспільства, з урахуванням реального стану його розвитку, а також готовності та спроможності громадян до впровадження цих технологій.

3 позиції теорії державного регулювання державну політику інформатизації варто розуміти як: сукупність основних напрямів і способів діяльності держави для створення, зміцнення та сприяння нормативноправового, методичного, організаційного, фінансового, матеріальнотехнічного, забезпечення загальнодержавних пріоритетів розвитку інформаційного середовища.

Сукупність інструментів державної політики інформатизації у загальному вигляді можна представити у розрізі правових та економічних регуляторів.

Основними правовими інструментами державного регулювання IT-індустрії в Україні є закони України: «Про Концепцію Національної програми інформатизації»; «Про Національну програму інформатизації», «Про телекомунікації», «Про пріоритетні напрями розвитку науки і техніки», «Про державне регулювання діяльності у сфері трансферу технологій», «Про наукову і науково-технічну діяльність», «Про Загальнодержавну комплексну програму розвитку високих наукоємних технологій», «Про державну підтримку розвитку індустрії програмної продукції», «Про стандарти, технічні регламенти та процедури відповідності» тощо.

У числі економічних регуляторів особливої уваги заслуговують такі як: створення умов для зростання IT-сектору, розвиток інформаційнотелекомунікаційних систем та формування інформаційних ресурсів в інтересах державного управління.

Сектор IT в Україні сьогодні займає дев'яте місце серед усіх видів економічної діяльності в структурі ВВП та створює майже 4\% валового продукту. У середньому галузь зростає на 20\% щороку [1]. 
За підсумками 2018 року відповідно до даних Державної служби статистики України у загальній структурі використання інформаційних технологій за видами підприємств найбільша частка належить підприємствам переробної промисловості $(25,15 \%)$, оптової та роздрібної торгівлі (24,7\%). У діапазон від 5 до 8\% потрапляють підприємства транспорту, складського господарства, поштової та кур'єрської діяльності, діяльності у сфері адміністративного та допоміжного обслуговування, операції з нерухомим майном [2].

Регіональна структура українського IT - досить нерівномірна. Більшість суб'єктів зареєстровано в обласних центрах та близько третини компаній розташовано в Києві. Значне представництво мають також міста Харків, Львів, Дніпро та Одеса.

Українська IT-галузь сьогодні успішно конкурує на світовому ринку і є надійним джерелом валютних надходжень до країни. Так, незважаючи на повільні темпи зростання експорту та економіки в цілому, галузь показувала стабільне зростання на 12\% щороку. Експорт ITпослуг 2018 року становив 2,1 млрд. дол. США [3]. Відповідно, зростає і значущість IT-послуг в структурі експорту країни. Так, у 2018 році IT-послуги посіли друге місце в структурі експорту послуг з України після транспортних послуг, збільшивши розрив із такими послугами як переробка матеріальних ресурсів (рис. 1).
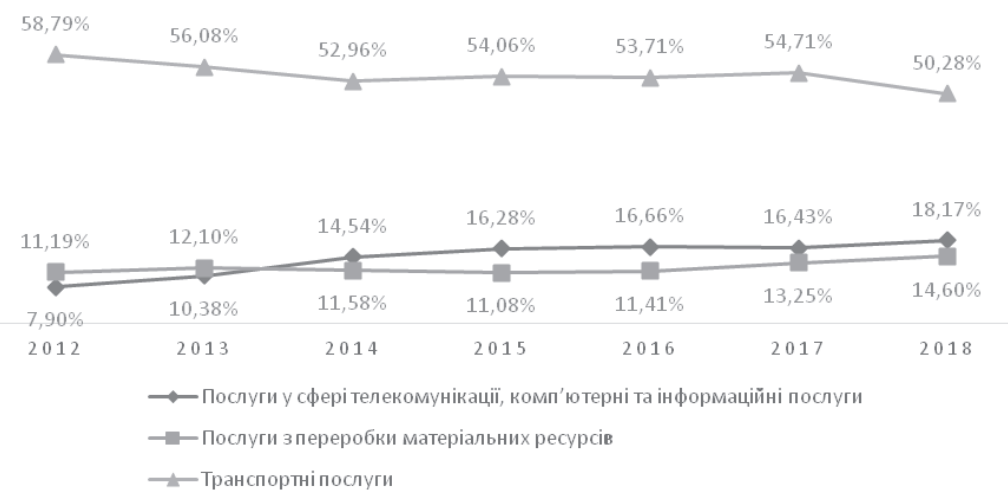

Рис. 1. Динаміка частки провідних експортооріснтованих галузей в структурі експорту послуг у 2018 році Джерело: складено авторами за даними [3] 
У цілому український IT-сектор та IT-ринок характеризуються переважно позицією постачальника на експорт не повного фінального продукту, а лише його елементів, тобто своєрідної «сировини».

Привертає увагу слабкість чинника цифрової конкурентоспроможності національної економіки (табл. 1). У 2018 р. індекс цифрової конкурентоспроможності України за даними Міжнародного інституту управлінського розвитку склав 51,3 (максимальне значення - 100,0), що відповідає 58 місцю з 63 країн. Зокрема, серед країн Європи та Близького Сходу, що включені у рейтинг, наша держава посіла останнє місце з 38 країн. У розрізі окремих складових індексу упродовж 20142018 рр. низькі рейтингові позиції наша держава посідала за напрямами технологічної конкурентоспроможності та готовності до майбутньої цифровізації. У 2018 році в розрізі такої складової індексу як знання, найнижчі позиції Україна демонструє за таким елементом цифрової конкурентоспроможності як «талант» (55 місце) та проведення науково-дослідної роботи (40 місце).

Таблиця 1

Місце України у рейтингу цифрової конкурентоспроможності в 2014-2018 pp.

\begin{tabular}{|c|c|c|c|c|c|c|c|}
\hline \multirow[b]{2}{*}{ Показники } & \multicolumn{5}{|c|}{ Роки } & \multicolumn{2}{|c|}{ Відхилення } \\
\hline & \begin{tabular}{|c|}
2014 \\
$(60$ кра- \\
їн $)$ \\
\end{tabular} & $\begin{array}{c}2015 \\
(61 \text { кра- } \\
\text { їна) }\end{array}$ & $\begin{array}{c}2016 \\
(61 \text { кра- } \\
\text { їна) }\end{array}$ & $\begin{array}{c}2017 \\
(63 \text { кра- } \\
\text { їни) }\end{array}$ & $\begin{array}{c}2018 \\
(63 \text { кра- } \\
\text { їни) }\end{array}$ & $\begin{array}{c}2018 / \\
2014\end{array}$ & $\begin{array}{c}2018 / \\
2017\end{array}$ \\
\hline 1 & 2 & 3 & 4 & 5 & 6 & 7 & 8 \\
\hline $\begin{array}{l}\text { Індекс цифрової } \\
\text { конкурентоспромож- } \\
\text { ності }\end{array}$ & 50 & 59 & 59 & 60 & 58 & $\downarrow 8$ & $\uparrow 2$ \\
\hline Знання & 29 & 40 & 44 & 45 & 39 & $\downarrow 10$ & $\uparrow 6$ \\
\hline Талант & 46 & 55 & 58 & 57 & 55 & $\downarrow 9$ & $\uparrow 2$ \\
\hline Навчання та освіта & 4 & 15 & 20 & 26 & 22 & $\downarrow 18$ & $\uparrow 4$ \\
\hline $\begin{array}{l}\text { Науково-дослідна } \\
\text { робота }\end{array}$ & 42 & 39 & 45 & 45 & 40 & $\uparrow 2$ & $\uparrow 5$ \\
\hline Технологіï & 58 & 60 & 60 & 62 & 61 & $\downarrow 3$ & $\uparrow 1$ \\
\hline $\begin{array}{l}\text { Нормативно-правова } \\
\text { база }\end{array}$ & 47 & 55 & 55 & 56 & 54 & $\downarrow 7$ & $\uparrow 2$ \\
\hline Капітал & 56 & 60 & 60 & 62 & 61 & $\downarrow 5$ & $\uparrow 1$ \\
\hline
\end{tabular}


Продовження таблиці 1

\begin{tabular}{|l|c|c|c|c|c|c|c|}
\hline \multicolumn{1}{|c|}{$\mathbf{1}$} & $\mathbf{2}$ & $\mathbf{3}$ & $\mathbf{4}$ & $\mathbf{5}$ & $\mathbf{6}$ & $\mathbf{7}$ & $\mathbf{8}$ \\
\hline $\begin{array}{l}\text { Технологічна інфра- } \\
\text { структура }\end{array}$ & 58 & 60 & 58 & 60 & 57 & $\uparrow 1$ & $\uparrow 3$ \\
\hline $\begin{array}{l}\text { Готовність до май- } \\
\text { бутнього }\end{array}$ & 58 & 61 & 61 & 61 & 61 & $\downarrow 3$ & - \\
\hline Адаптивне ставлення & 58 & 60 & 60 & 58 & 53 & $\uparrow 5$ & $\uparrow 5$ \\
\hline Ділова активність & 42 & 58 & 59 & 56 & 53 & $\downarrow 11$ & $\uparrow 3$ \\
\hline ІТ-інтеграція & 58 & 61 & 60 & 60 & 61 & $\downarrow 3$ & $\downarrow 1$ \\
\hline
\end{tabular}

Джерело: складено авторами за матеріалами [4]

Життєво важливим фактором та підгрунтям для функціонування та розвитку української IT-індустрії $є$ екосистема. Вона поєднує профільні бізнес-асоціації, інфраструктуру стартапів, регіональні об'єднання (кластери), заклади вищої освіти, що активно розвивають напрям технічної освіти та приватні освітні проекти, інноваційні парки, технологічні хаби, масштабні індустріальні події, професіональні формальні та неформальні спільноти. Кожен з цих елементів має свої пріоритети та вектори роботи, що в результаті створює позитивні умови для розвитку галузі у цілому.

Активно екосистема для IT-бізнесу в Україні почала розвиватися лише впродовж останніх кількох років. Головною причиною для цього $\epsilon$ стрімке зростання галузі, поява нових гравців на ринку.

Так, сьогодні в Україні функціонує 17 регіональних об’єднань (ITкластерів). Ключовими напрямами їх діяльності є модернізація та розвиток ІТ-освіти в межах міст та регіонів, охоплених полем їх діяльності; діалог з органами місцевої влади; формування позитивного іміджу країни та регіону на міжнародній арені [5, с. 70].

Участь у бізнес-асоціаціях характерна для великих та середніх за розмірами IT-компаній. Така специфіка зумовлена, перш за все, векторами роботи даного типу спільнот. Для асоціацій, на відміну від кластерів, характерні проекти у сфері Government Relations національного масштабу. Це стосується більшості напрямків роботи: створення законодавчих ініціатив задля гармонійного розвитку IT-бізнесу, модернізації освітньої системи, просування індустрії за кордоном тощо.

Перспективним для України є розвиток бізнес-інкубаторів. Ті з них, що створені та функціонують сьогодні здебільшого існують за рахунок 136 
коштів міжнародних фондів, грантових програм та фінансування інших міжнародних донорських організацій.

Важливим елементом для підтримки розвитку стартапів $є$ хаби та інноваційні центри. Для даного елементу екосистеми характерне об'єднання представників бізнесу в рамках однієї території, що має на меті створення сприятливого підприємницького середовища, пожвавлення обміну досвідом шляхом співпраці та менторства.

Варто зазначити, що у багатьох країнах держава не тільки формує юридично-правові засади функціонування стартапів, але й виступає інвестором, бере участь у створенні інноваційних центрів, технопарків тощо. В Україні роль держави як суб'єкта екосистеми стартапів поки що мінімальна. Сьогодні в українському законодавстві відсутнє визначення стартап-компаній, а правові засади їх функціонування (як і ведення онлайн-комерції) неврегульовані [6].

Зазначене вище, дає підстави зробити висновок відносно того, що однією із перешкод та проблем, що заважає розвитку найбільш перспективної галузі XXI століття в Україні є недорозвинена екосистема. У держави немає програм підтримки розвитку вказаних елементів IT-інфраструктури, відповідно відсутня фінансова їх підтримка за рахунок бюджетних коштів. Сучасній екосистемі бізнесу не вистачає каналів комунікацій між постачальниками та споживачами.

Подальший розвиток і реалізація потенціалу IT-сфери України потребує застосування відповідних економічних інструментів державної регуляторної політики. Зокрема:

- розвиток регіональної інноваційної інфраструктури інтеграції науково-дослідної та виробничої діяльності (технопарків, індустріальних парків, венчурних фондів, центрів трансферу технологій та ін.), яка включає весь інноваційний ланцюг від розвитку фундаментальної наукової ідеї до виробництва та дистрибуції готової IT-продукції на зовнішніх та внутрішніх ринках;

- популяризація кластерної моделі розвитку ІТ-галузі шляхом запровадження пакету фіскальних стимулів для учасників IT-кластерів. При цьому рівень державної допомоги має бути обернено пропорційним до відношення показника ВВП на душу населення в регіоні розміщення ІТ-кластеру до середнього значення ВВП на душу населення в Украйні [76, с. 288]; 
- удосконалення бізнес-середовища для всіх гравців телекомунікаційного ринку України, спрощення процедури отримання дозволів та ліцензій, забезпечення рівних умов доступу до телекомунікаційної інфраструктури, а також розробку механізмів захисту критично важливих компонентів IT-інфраструктури, які виключають можливість примусового вимкнення мереж та вилучення серверного обладнання.

Запровадження окреслених інструментів визначатиме подальший розвиток «цифрових трансформацій» України. Розвиток подій можливий за одним із двох сценаріїв - базовим та форсованим.

Базовий сценарій, або непріоритетний передбачає інерційне продовження тенденцій сприйняття процесу розвитку IT-індустрії як непріоритетної, що буде і надалі призводити до трудової міграції та відтоку кадрів, низької конкурентоспроможності програмної продукції українського виробництва, збереженню за Україною статусу так званого «ІТ-офшору» зі спеціалізацією не на створенні наукоємного кінцевого продукту, а на постачанні часткових проектних рішень в рамках складеної моделі аутсорсингу. За Україною продовжить зберігатися статус найбільш толерантної до використання неліцензійного програмного забезпечення держави, що продовжить утримувати низький рівень попиту на інформаційні технології на внутрішньому ринку. У короткостроковій перспективі цей сценарій матиме лише незначний вплив на модернізацію економіки, розвиток ринку інновацій, інноваційного підприємництва та загального стану «цифровізації» країни. Проте у довгостроковій перспективі $є$ значний ризик упустити мультиплікативний ефект від впровадження інформаційних технологій, що посилить відставання України від провідних постіндустріальних економік.

Форсований, або пріоритетний, сценарій цифровізації передбачає усунення законодавчих, інституційних, фіскально-податкових, валютно-грошових бар'єрів, що перешкоджають розвитку сектора інформаційних технологій. Головною мотивацією держави обрати цей сценарій розвитку є отримувані дивіденди, а саме: загальнонаціональний економічний приріст; прискорення автоматизації виробничих процесів, зростання продуктивності праці та, відповідно, українських підприємств; зниження рівня тонізації економіки; зростання ВВП; надходження більшої кількості податків за рахунок зростаючої бізнес-активності; підвищення ефективності управління; прозорість, простота та оперативність взаємодії населення та суб' єктів господарювання з державни138 
ми органами влади; розширення присутності української продукції на світових ринках; позитивний ефект для суспільства, що проявлятиметься у більш оперативному обміні даними та інформацією, удосконаленні споживчих товарів і послуг відповідно до вимог населення.

Моделювання економічних процесів за допомогою кореляційнорегресійного аналізу дозволило побудувати модель залежності обсягу ринку IT від двох показників: обсягу капітальних інвестицій та обсяг експорту.

Двофакторне рівняння для обсягу ринку має такий вигляд:

$$
y=9565+24,55 \times K I+18,87 \times E
$$

де КІ - обсяг капітальних інвестицій, млн. грн. на рік;

Е - обсяг експорту, млн. дол. США на рік.

Отримана модель має наступні параметри: коефіцієнт кореляції на основі даних 2010-2018 рр. склав 0,9787, коефіцієнт детермінації на рівні 0,9579, а стандартна помилка дорівнює 8506,4 млн. грн.

За допомогою двофакторного кореляційно-регресійного аналізу спрогнозовано загальний обсяг ринку IT в Україні (табл. 2). За результатами аналізу з ймовірністю 95,8\% у 2019 році ринок IT складатиме 157274,3 млн. грн., у 2020-193424,1 млн. грн. і 2021 року 240001,9 відповідно.

Таблиця 2

Прогноз обсягів IT-ринку

\begin{tabular}{|l|c|c|c|c|c|c|}
\hline \multicolumn{1}{|c|}{ Показник } & \multicolumn{2}{|c|}{2019} & \multicolumn{2}{c|}{2020} & \multicolumn{2}{c|}{2021} \\
\hline $\begin{array}{l}\text { Капітальні } \\
\text { iнвестиції, млн. } \\
\text { грн. }\end{array}$ & \multicolumn{2}{|c|}{4284,5} & \multicolumn{2}{|c|}{5633,6} & \multicolumn{2}{|c|}{7407,5} \\
\hline $\begin{array}{l}\text { Обсяг експорту } \\
\text { IT-послуг, млн. } \\
\text { дол. США }\end{array}$ & \multicolumn{2}{|c|}{2247,1} & \multicolumn{2}{|c|}{2407,8} & \multicolumn{2}{|c|}{2568,5} \\
\hline $\begin{array}{l}\text { Обсяг IT-ринку, } \\
\text { млн. грн. }\end{array}$ & мін. & макс. & мін. & макс. & мін. & макс. \\
\cline { 2 - 7 } & 148767,8 & 165780,7 & 184917,7 & 201930,5 & 231495,5 & 248508,4 \\
\hline
\end{tabular}

Джерело: розраховано авторами 
Отже, за результатами прогнозування можна судити про позитивну тенденцію до зростання обсягу ринку IT у 2019-2021 pp.

Висновки 3 даного дослідження і перспективи подальших розробок за даним напрямом. Результати проведених досліджень дозволяють констатувати, що державне регулювання IT-індустрії являє собою комплекс заходів впливу держави на процеси, що відбуваються у секторі інформаційних технологій, із застосуванням політичних та економічних регуляторів. Державна політика інформатизації має формуватися як складова соціально-економічної політики держави і спрямовується на раціональне використання промислового та науково-технічного потенціалу, матеріально-технічних і фінансових ресурсів для створення сучасної інформаційної інфраструктури в інтересах вирішення комплексу поточних та перспективних завдань розвитку національної економіки. Пріоритети державної регуляторної політики у сфері інформаційних технологій першочергово мають забезпечити відповідність нормативно-правової бази сучасним потребам взаємовідносин суб'єктів господарювання, створення сучасної інформаційної інфраструктури, інформатизації соціальної сфери, фінансової та грошової системи, створення відповідної стимулюючої політики.

Галузь інформаційних технологій є індустрією знань, талантів та експертизи, тому головне завдання IT-екосистеми полягає у тому, аби забезпечити постійну взаємодію учасників ринку на різних рівнях у площині обміну досвідом та комунікації для вирішення спільних завдань, що стоять перед гравцями ринку, а завдання держави у даному напрямку - усіляко цьому сприяти, розроблюючи відповідні програми підтримки, надавати інституціонально-інвестиційну підтримку. До такої екосистеми відносяться профільні бізнес-асоціації, стартапи, регіональні об'єднання (кластери), заклади вищої освіти, що активно розвивають напрям технічної освіти та приватні освітні проекти, інноваційні парки, технологічні хаби, масштабні індустріальні події, професіональні формальні та неформальні спільноти. Кожен з цих елементів має свої пріоритети та вектори роботи, що в результаті створює позитивні умови для розвитку галузі.

Для подолання низки проблем, які сьогодні постали перед ITсферою, та стимулювання прискореного розвитку галузі необхідно реалізувати комплекс заходів у сфері державної регуляторної політики за такими напрямами як бюджетно-податкове стимулювання; вдоско140 
налення нормативно-правової бази та її гармонізація з міжнародними правовими нормами; покращення інтелектуально-кадрового забезпечення як ключового ресурсу подальшого розвитку IT-сфери; реалізація інфраструктурно-економічного інструменту підтримки IT-сфери.

Моделювання економічних процесів за допомогою кореляційнорегресійного аналізу дозволило визначити, що у перспективі варто очікувати подальше розширення обсягів IT-ринку, збільшення експорту IT-продукції та стрімке зростання капітальних інвестицій у галузь.

\section{Лimepamypa}

1. The Global Outsourcing / Компанія AIOP : сайт. URL: https:// www.iaop.org/Content/19/165/4454 (дата звернення: 02.07.2019).

2. Використання інформаційно-комунікаційних технологій на підnриємствах / Державна служба статистики України: сайт. URL: https:// ukrstat.org/uk/operativ/operativ2018/zv/ikt/arh_ikt_u.html (дата звернення: 02.07.2019).

3. Динаміка зовнішньої торгівлі послугами за видами / Державна служба статистики України: сайт. URL: http://www.ukrstat.gov.ua/operativ/ operativ2008/zd/dseip/dseip2007_u.htm (дата звернення: 05.07.2019).

4. Рейтинг цицррової конкурентоспроможності / Міжнародний інститут управлінського розвитку IMD : сайт. URL: https:/www.imd.org/wcc/ world-competitiveness-center-rankings/world-digital-competitiveness-rankings/ (дата звернення: 10.07.2019).

5. Федулова Л. I. Organizational and Institutional Preconditions to the Formation of Technological Clusters as Ukrainian Economy Growth Points. Наука та інновачіï. 2011. № 2. C. 25-34. DOI: doi.org/10.15407/scin7.02.025.

6. Щодо державної реєстрації іноземних інвестииій. Сайт Територіальних органів ДФС у Чернігівській області. URL: http://ch.sfs.gov.ua/ media-ark/news-ark/312394.html (дата звернення: 15.07.2019).

7. Лесько О. Й. Шляхи забезпечення інформаційних процесів кластеризації економіки в Україні : матеріали XLVI наук.-техніч. конф. підрозділів Вінницького національного технічного університету (Вінниця, 22-24 березня 2017 р.). URL: https://conferences.vntu.edu.ua/ index.php/all-fm/ all-fm-2017/paper/view/2180 (дата звернення: 15.07.2019).

\section{References}

1. The Global Outsourcing. Kompaniya AIOP: sait [AIOP company: Site]. Retrieved from: https://www.iaop.org/Content/19/165/4454 
2. Vykorystannia informatsiino-komunikatsiinykh tekhnolohii na pidpryiemstvakh [Use of information and communication technologies at enterprises]. Derzhavna sluzhba statystyky Ukrainy: sait [State Statistics Service of Ukraine: site]. Retrieved from: https://ukrstat.org/uk/operativ/operativ2018/ zv/ikt/arh_ikt_u.html [in Ukrainian]

3. Dynamika zovnishnoi torhivli posluhamy za vydamy [Dynamics of foreign trade in services by types]. Derzhavna sluzhba statystyky Ukrainy: sait [State Statistics Service of Ukraine: site]. Retrieved from: http://www.ukrstat.gov.ua/operativ/operativ2008/zd/dseip/dseip2007_u.htm [in Ukrainian]

4. Reitynh tsyfrovoi konkurentospromozhnosti [Digital competitiveness rating]. Mizhnarodnyi instytut upravlinskoho rozvytku IMD: sait [International Institute for management development IMD: site]. Retrieved from: https:// www.imd.org/wcc/world-competitiveness-center-rankings/world-digitalcompetitiveness-rankings [in Ukrainian]

5. Fedulova, L. I. (2011). Orhanizatsiino-instytutsiini peredumovy formuvannia tekhnolohichnykh klasteriv yak tochok rostu ekonomiky Ukrainy [Organizational and institutional preconditions to the formation of technological clusters as Ukrainian economy growth points]. Nauka ta innovatsii - Science and Innovations, 2, 25-34. DOI: doi.org/10.15407/scin7.02.025 [in Ukrainian]

6. Shchodo derzhavnoi reiestratsii inozemnykh investytsii [Regarding state registration of foreign investment]. Sait Terytorialnykh orhaniv DFS $\mathrm{u}$ Chernihivskii oblasti [Site of the territorial bodies of the State Fiscal Service in Chernihiv region]. Retrieved from: http://ch.sfs.gov.ua/media-ark/newsark/312394.html [in Ukrainian]

7. Lesko, O. Y. (2017). Shliakhy zabezpechennia informatsiinykh protsesiv klasteryzatsii ekonomiky v Ukraini: materialy XLVI naukovo-tehknichnoi konferentsii pidrozdiliv Vinnytskoho natsionalnoho tekhnichnoho universytetu [Ways of providing information processes of economy clustering in Ukraine: Proceedings of XLVI scientific and technical conference of Vinnitsa national technical university departments], Vinnitsia, 22-24 bereznia 2017 r. Retrieved from: https://conferences.vntu.edu.ua/ index.php/all-fm/all-fm-2017/paper/ view/2180 [in Ukrainian] 